\title{
Mathematical modeling of the drying kinetics of the leaves of lemon grass (Cymbopogon citratus Stapf) and its effects on quality
}

\author{
Modelación matemática de la cinética de secado de las hojas de hierba de limón \\ (Cymbopogon citratus Stapf) y sus efectos sobre la calidad
}

\author{
Paulo Carteri Coradi ${ }^{1 *}$, Evandro de Castro Melo ${ }^{2}$, Rocinely Pereira da Rocha ${ }^{3}$
}

\begin{abstract}
The aim of this study was evaluate the drying of the lemon grass plant (Cymbopogon citratus Stapf) at different air temperatures $\left(40{ }^{\circ} \mathrm{C}, 50{ }^{\circ} \mathrm{C}, 60{ }^{\circ} \mathrm{C}\right.$ and $70{ }^{\circ} \mathrm{C}$ ) to adjust the experimental data obtained with different mathematical models and assess the quality of the plant after drying. A completely randomized design (CRD) was used with three drying replications for each speed and temperature of the drying air. The essential oil content extracted from the dried plant at $0.8 \mathrm{~m} \mathrm{~s}^{-1}$ and $1.3 \mathrm{~m} \mathrm{~s}^{-1}$ with manual control system was not affected by the drying process; the temperature of the drying air had a negative influence on the levels of the essential oil of the plant; drying with automatic control decreased the essential oil content for all velocities studied compared to the fresh plant; increments in the temperature of the drying air significantly reduced drying time. The mathematical model of Two Terms is adequate to describe the drying process of lemon grass plant (Cymbopogon citratus Stapf); diffusion values increased with increasing temperature of the drying air, while the value of activation energy was $62.84 \mathrm{~kJ} \mathrm{~mol}^{-1}$.
\end{abstract}

Key words: air, control, plant, velocity, temperature.

\section{RESUMEN}

El objetivo de este estudio fue evaluar el secado de la planta de hierba de limón (Cymbopogon citratus Stapf) a diferentes temperaturas de aire $\left(40^{\circ} \mathrm{C}, 50^{\circ} \mathrm{C}, 60^{\circ} \mathrm{C}\right.$ y $\left.70^{\circ} \mathrm{C}\right)$ para ajustar los datos experimentales obtenidos con diferentes modelos matemáticos y evaluar la calidad de la planta después del secado. Un diseño completamente al azar (DCA) se utilizó con tres repeticiones para cada velocidad de secado y la temperatura del aire de secado. El contenido de aceite esencial extraído de la planta seca en 0,8 $\mathrm{m}$ $\mathrm{s}^{-1}$ y $1,3 \mathrm{~m} \mathrm{~s}^{-1}$ con sistema de control manual no se vio afectado por el proceso de secado, la temperatura del aire de secado tuvo una influencia negativa sobre la reducción de los niveles del aceite esencial de la planta, el secado con control automático de disminución del contenido de aceite esencial para todas las velocidades estudiado en comparación la planta fresca; incrementa el valor de la temperatura del aire de secado ha reducido significativamente el equipo de secado, el modelo matemático de Dos Términos es adecuada para describir el proceso de secado de la planta de hierba de limón (Cymbopogon citratus Stapf), los valores de difusión aumentó con el aumento de temperatura del aire de secado, mientras que el valor de la energía de activación es $62.84 \mathrm{~kJ} \mathrm{~mol}^{-1}$.

Palabras clave: aire, control, velocidad, temperatura.

\section{Introduction}

Lemon grass (Cymbopogon citratus Stapf) is widely cultivated in Brazil and utilized for medicinal purposes, especially as tea, and industries are investing in it due to its essential oil. The growing demand for medicinal species indicates the emergence of a market with high potential for consumption, requiring raw material of high quality, with regular supply and easy availability. The drying process may also contribute to regular supply and facilitate the marketing of plants, because it facilitates transport and storage (Castro \& Ferreira, 2001). In the literature several methods are mentioned to analyze the drying of hygroscopic products (theoretical, empirical and semiempirical). The empirical method is a method based on experimental data and dimensionless analysis. The empirical models of drying show a direct relationship

\footnotetext{
Federal University of Mato Grosso do Sul, Campus of Chapadão do Sul, Brazil.

Federal University of Viçosa, Department of Agricultural Engineering, Brazil.

Federal University of Viçosa, Department of Agricultural Engineering, Brazil.

* Corresponding Author: paulo.coradi@ufms.br
} 
between average moisture content and drying time. However, this method omits the fundamentals of the drying process and its parameters have no physical meaning, therefore it does not provide an accurate view of the important processes that occur during the phenomenon while describing the drying curves for certain experimental conditions. The model of Thompson et al. (1968) has traditionally been used in studies of drying agricultural products and foodstuffs. Much emphasis has been given to developing semitheoretical models for achieving harmony between theory and ease of use. Such models are generally based on Newton's Law of Cooling applied to mass transfer. When applying this law it is assumed that conditions are isothermal and resistance to moisture transfer is confined only to the surface of the product (Brooker et al., 1992). Among semi-theoretical models, the model of two terms, the Henderson and Pabis, Lewis, Page and Modified Page and Panchariya et al. (2002) have been widely used. Currently, research on the study of the kinetics of thin layer drying is performed with various agricultural products such as seeds, grains, fruits and some plant species with economic importance. The conditions of the drying process that fit different models to each specific situation are observed. Panchariya et al. (2002) set various equations to the drying process of black tea and concluded that the model of Lewis reproduced best experimental data of thin layer drying in temperature ranges from 80 to $120{ }^{\circ} \mathrm{C}$. However, Demir et al. (2004), evaluating different mathematical models for drying of laurel (Laurus nobilis L.), found the Page model to be the one that best described the process, while Doymaz (2006), who evaluated drying of leaves of dill (Anethum graveolens L.) and parsley (Petroselinum crispum L.), defined the Midilli model as the most suitable to describe the drying curves at temperatures of 40 to $70^{\circ} \mathrm{C}$. The aim of the present study is to fit mathematical models and evaluate the quality of plants using thin layer drying and the experimental data obtained in drying leaves of lemon grass Cymbopogon citratus (DC) Stapf at different drying air temperatures.

\section{Material and Methods}

\subsection{Drying of lemon grass}

The species (Cymbopogon citratus (D.C.). Stapf) utilized for the drying tests was cultivated at the experimental area of the Agricultural Engineering
Department at the Federal University of Viçosa-UFV (Minas Gerais, Brazil). The lemon grass was harvested between 8:00 and 9:00 am and the samples were taken immediately to the laboratory for selection, moisture content determination and cooled in refrigerated chamber at $5{ }^{\circ} \mathrm{C}$ for subsequent drying. A fixedbed dryer with upward air flow was used, which contained 4 perforated trays with upward air flow and three electrical resistances for heating the drying air (Figure 1). Another experiment was conducted by varying the temperature of the drying air (40, 50,60 and $70{ }^{\circ} \mathrm{C}$ ). Each drying test was performed using $250 \mathrm{~g}$ of lemon grass leaves, making a layer of $5 \mathrm{~cm}$ thick in the drying chamber. The leaves were cut in $2 \mathrm{~cm}$ lengths and the drying air temperature was kept at $50{ }^{\circ} \mathrm{C}$, because essential oil content and active principle concentration are high at this length and temperature, as described by Martinazzo et al. (2010). Only one of the dryer trays, dryer chamber three, was filled with lemon grass leaves (Figure 1a). The reason for not completely filling all trays was due to the amount of plant sample available. The control of the temperature and velocity of drying air were done with an automatic controller as described by Prates et al. (2011). The dryer's manual control was by regulation (opening and closing) of the diaphragm (Figure 1b). Temperature data was taken with the use of thermocouples previously calibrated and placed in pre-set points of the dryer. Drying air velocity was tracked by an anemometer $\left(0.8 \mathrm{~m} \mathrm{~s}^{1}, 1.3 \mathrm{~m} \mathrm{~s}^{-1}\right.$ and $\left.1.8 \mathrm{~m} \mathrm{~s}^{-1}\right)$. The data of temperature and velocity of drying air were taken in an automatic data acquisition system that recorded their values in a microcomputer. The moisture content of the samples was determined using the gravimetric method recommended by ASAE Standards (2000).

\subsection{Determination of oil essential content}

After drying, samples were packed in polyethylene bags $(40 \mu \mathrm{m})$ and stored in a refrigerated chamber at $5{ }^{\circ} \mathrm{C}$ until being submitted to extraction of the essential oil. The essential oil was extracted by hydro distillation utilizing Clevenger equipment adapted to a round-bottomed two liter flask.

\subsection{Mathematical modeling}

The drying curves were fitted to the experimental data using thirteen different semi-empirical and empirical equations detailed below. 


$$
\begin{array}{cc}
\text { Equation } & \text { Model } \\
R U=\exp (-k \cdot t) & \text { Newton } \\
\mathrm{RU}=\exp \left(-\mathrm{k} \cdot \mathrm{t}^{\mathrm{n}}\right) & \text { Page } \\
\mathrm{RU}=\exp \left(-(\mathrm{k} \cdot \mathrm{t})^{\mathrm{n}}\right) & \text { Page Modified } \\
R U=\exp \left(-a-\left(a^{2}+4 \cdot b \cdot t\right)^{1 / 2}\right) / 2 \cdot b & \text { Thompson } \\
R U=\frac{1}{U-U e}=\frac{8}{\pi} \sum_{n-0}^{\infty} \frac{1}{(2 n+1)} \exp \left[-(2 n+1) \pi D \frac{t}{4 L}\right] & \text { Eight Diffusion Terms } \\
R U=a \cdot \exp (-k \cdot t) & \text { Henderson and Pabis } \\
R U=a \exp (-k t)+c & \text { Logarithmic } \\
R U=a \cdot \exp \left(-k_{o} \cdot t\right)+b \cdot \exp \left(-k_{1} \cdot t\right) & \text { Two Terms } \\
R U=a \cdot \exp (-k \cdot t)+(1-a) \exp (-k \cdot a \cdot t) & \text { Two Exponential Terms } \\
R U=1+a t+b t^{2} & \text { Wang and Singh } \\
R U=a \cdot \exp (-k \cdot t)+b \cdot \exp \left(-k_{o} \cdot t\right)+c \cdot \exp \left(-k_{1} \cdot t\right) & \text { Henderson and } \\
R U=a \cdot \exp \left(-k \cdot t^{n}\right)+b \cdot t & \text { Pabis Modified } \\
R U=a \cdot \exp (-k \cdot t)+(1-a) \cdot \exp (-k \cdot b \cdot t) & \text { Midilli }
\end{array}
$$

where

RU : Moisture ratio, dimensionless;

$\mathrm{t} \quad$ : drying time, $\mathrm{h}$;

$\mathrm{k}, \mathrm{k}_{\mathrm{o}}, \mathrm{k}_{1} \quad$ : drying constant, h-1;

$\mathrm{a}, \mathrm{b}, \mathrm{c}, \mathrm{n}$ : model coefficients;

$\mathrm{n} \quad$ : number of terms of the equation;

D : diffusion coefficient, $\mathrm{m} 2 \mathrm{~s}-1$;

L : product thickness, $\mathrm{m}$

To determine the ratios of moisture during drying air under different conditions we used the following expression:

$$
R U=\frac{U^{*}-U_{e}^{*}}{U_{i}^{*}-U_{e}^{*}}
$$

where

$\mathrm{U}^{*}$ : water content of product (\% d.b.);

$\mathrm{U}_{\mathrm{i}}{ }^{*}$ : initial water content of the product (\% d.b.); $\mathrm{U}_{\mathrm{e}}{ }^{*}$ : equilibrium water content of the product (\% d.b.).
The hygroscopic moisture equilibrium (Ue) was determined by equation 15 proposed by Corrêa $e t$ $a l$. (2002) for medicinal plants, with its parameters determined by the desorption process.

$$
U e=\frac{1}{\left(a \cdot T^{b}+U R^{c}\right)}
$$

where

T: air temperature, ${ }^{\circ} \mathrm{C}$;

UR: relative humidity, decimal

$\mathrm{a}, \mathrm{b}, \mathrm{c}$ : constants that depend on the nature of the product.

In the case of lemon grass: $a=-1.0484, b=-0.0221$ and $\mathrm{c}=-0.0628$.

It is usual to consider the value of the diffusion coefficient constant or linearly dependent on the temperature of the drying air. This relationship was expressed by the Arrhenius model (Park et al., 2002).

$$
D=A \exp \left(-\frac{E}{R T}\right)
$$




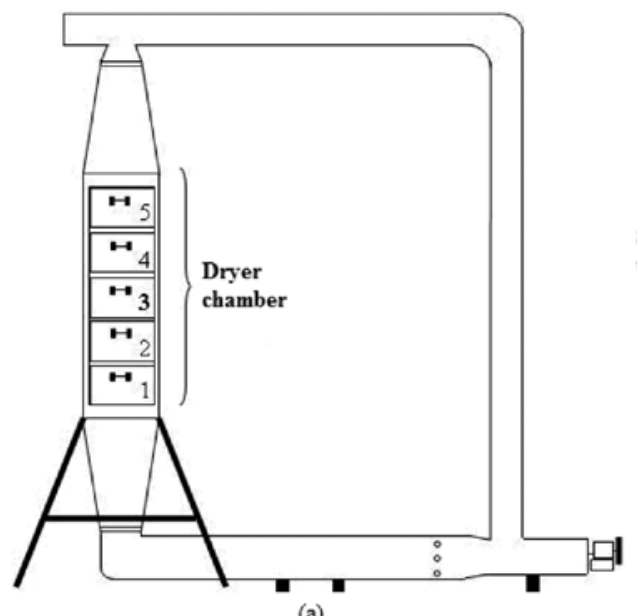

(a)

Figure 1. Front view (a) and frontal section (b) of dryer.

where

A: constant $\left(\mathrm{m}^{2} \mathrm{~s}^{-1}\right)$;

E: activation energy $\left(\mathrm{kJ} \mathrm{kmol}^{-1}\right)$;

$\mathrm{R}$ : universal gas constant $\left(8.314 \mathrm{~kJ} \mathrm{kmol}^{-1} \mathrm{~K}^{-1}\right)$; $\mathrm{T}_{\mathrm{abs}}:$ absolute temperature $(\mathrm{K})$.

The coefficients of the Arrhenius expression were linearized by applying the logarithm of the form:

$$
\operatorname{Ln} D=\operatorname{Ln} A-\frac{E}{R T} \frac{1}{T a}
$$

Data was analyzed using analysis of variance and regression by $\mathrm{F}$ test, adopting the 5\% level of significance.

\subsection{Statistical analysis}

The quantitative and qualitative factors were analyzed using the program SISVAR ${ }^{\circledR} 4.3$ and the results were compared by Tukey tests, using $5 \%$ probability. The experimental design was a completely randomized design (CRD) with three tests for each drying air velocity and drying temperature. To adjust the mathematical models analyses nonlinear regressions were performed using the Quasi-Newton method in the computer program STATISTICA 7.0 ${ }^{\circledR}$. To check the degree of fit of each model the significance of the regression coefficient was evaluated by t-tests, adopting the 5\% level of probability, the magnitude of the coefficient of determination $\left(\mathrm{R}^{2}\right)$, the mean relative error values
(P) and the average estimated error (SE), and verified by the behavior of the distribution of residuals. The relative average error and the average error estimated for each model were calculated according to the following expressions, respectively:

$$
\begin{gathered}
P=\frac{100}{n} \sum \frac{|Y-\hat{Y}|}{Y} \\
S E=\sqrt{\frac{\sum(Y-\hat{Y})^{2}}{G L R}}
\end{gathered}
$$

where

Y: experimentally observed value;

$\hat{Y}$ : value calculated by the model;

$\mathrm{N}$ : number of experimental observations;

GLR: degrees of freedom of the model (the number of observations minus the number of model parameters).

\section{Results and Discussion}

\subsection{Drying velocity and essential oil content}

Table 1 shows the moisture content of fresh plant and from dried samples, acquired during the drying process using manual and automatic control of air velocity, respectively. It also reports the mean of air temperature and total time of drying, with their standard deviations for the drying treatments with air velocity of $0.8 \mathrm{~m} \mathrm{~s}^{-1}, 1.3 \mathrm{~m} \mathrm{~s}^{-1}$ and 1.8 $\mathrm{m} \mathrm{s}^{-1}$. The velocity of the drying air is one of the 
Table 1. Parameters evaluated during the drying process of lemon grass using manual and automatic control of air velocity.

\begin{tabular}{lcccc}
\hline $\begin{array}{c}\text { Drying air velocity } \\
(\mathrm{m} \mathrm{s}-1)\end{array}$ & $\begin{array}{c}\text { Moisture content } \\
\text { of fresh plant (d.b.) }\end{array}$ & $\begin{array}{c}\text { Moisture content } \\
\text { of dried plant (d.b) }\end{array}$ & Drying time (min) & Temperature $\left({ }^{\circ} \mathrm{C}\right)$ \\
\hline Manual control & $3.12 \pm 0.31$ & $0.13 \pm 0.01$ & $220 \pm 20$ & $50.3 \pm 0.96$ \\
0.8 & $3.12 \pm 0.31$ & $0.11 \pm 0.01$ & $200 \pm 10$ & $49.9 \pm 1.23$ \\
1.3 & $3.12 \pm 0.31$ & $0.12 \pm 0.02$ & $190 \pm 10$ & $50.2 \pm 0.87$ \\
1.8 & & & & \\
Automatic control & $3.12 \pm 0.31$ & $0.11 \pm 0.09$ & $220 \pm 20$ & $50.4 \pm 0.97$ \\
0.8 & $3.12 \pm 0.31$ & $0.11 \pm 0.01$ & $200 \pm 10$ & $49.9 \pm 0.92$ \\
1.3 & $3.12 \pm 0.31$ & $0.12 \pm 0.01$ & $190 \pm 10$ & $50.4 \pm 0.84$ \\
\hline
\end{tabular}

parameters which must be controlled to obtain good quality products. According to Hansen et al. (1993), increasing the flow rate of the drying air exerts a greater influence in reducing the drying time of the temperature in places of low relative humidity. There are wide variations in the values of air velocity recommended for medicinal plants. Some authors such as Hansen et al. (1993) used a speed of 0.039 $\mathrm{m} \mathrm{s}^{-1}$ in a fixed bed dryer working with thin layers of shaved Taxus x media Hicksii. In the drying of basil (Ocimum basilicum L.), the speed used by Baritaux et al. (1992) was $0.4 \mathrm{~m} \mathrm{~s}^{-1}$. The highest value found was $3.3 \mathrm{~m} \mathrm{~s}^{-1}$, used by Venskutonis $e t$ al. (1996) drying thyme (Thymus vulgarius L.) and sage (Salvia L. officinales). Figure 2 shows the results obtained in the statistical analysis of the essential oil content extracted from the fresh plant (control) and from the samples submitted to the drying process with different drying air velocities $\left(0.8 \mathrm{~m} \mathrm{~s}^{-1}, 1.3\right.$ $\mathrm{m} \mathrm{s}^{-1}$ and $1.8 \mathrm{~m} \mathrm{~s}^{-1}$ ) and different control systems (automatic and manual). From the results observed in Figure 2 it may be concluded that the drying air velocities of $0.8 \mathrm{~m} \mathrm{~s}^{-1}$ and $1.3 \mathrm{~m} \mathrm{~s}^{-1}$ with manual control system increased the essential oil extraction from lemon grass leaves compared to the automatic control; however, when compared to fresh plants (control) there was no significant difference. All dried samples from the automatic control system at all drying air velocities decreased the essential oil content compared to fresh plants. There was no significant difference in the drying air velocity of $1.8 \mathrm{~m} \mathrm{~s}^{-1}$ with automatic and manual compared to the fresh plant reductions of 32 and $33 \%$ in essential oil content, respectively. Akpinar (2006) studied the influence of 4 drying air temperatures $(40,50$, 60 and $70{ }^{\circ} \mathrm{C}$ ), in thin layers and 2 air velocities $\left(0.9\right.$ and $\left.1.9 \mathrm{~m} \mathrm{~s}^{-1}\right)$ on the essential oil content of Ocimum basilicum. The highest essential oil

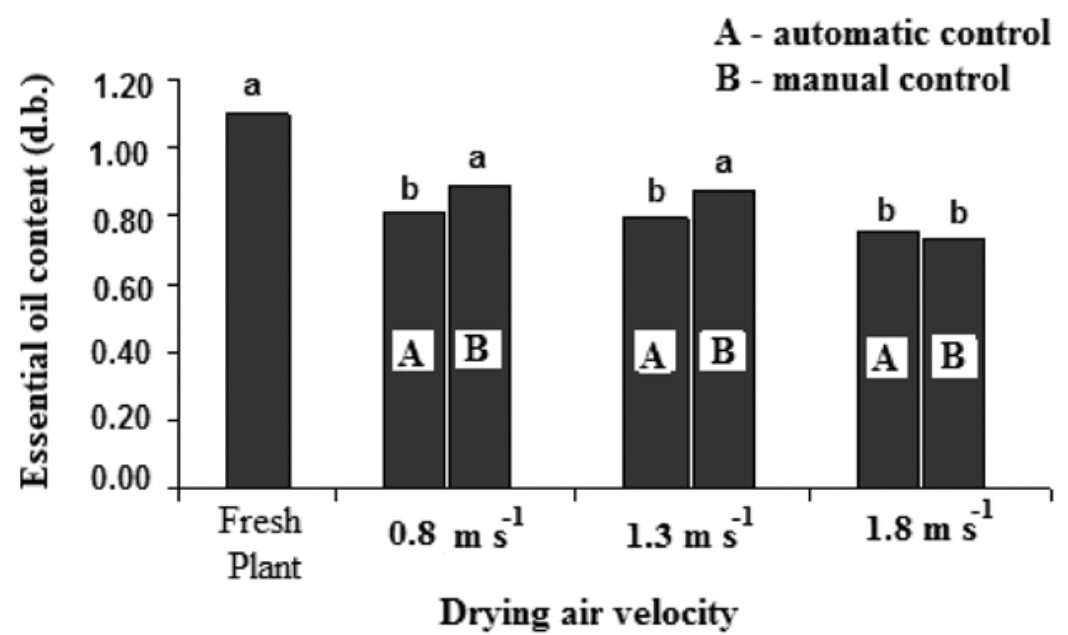

Figure 2. Essential oil content from fresh and dried plant in different control systems (automatic and manual) and air velocities. 
content was obtained in the drying process with an air temperature of $40{ }^{\circ} \mathrm{C}$ and air velocity of 1.9 $\mathrm{m} \mathrm{s}^{-1}$. The essential oil of Ocimum basilicum was affected by both temperature and air velocity during drying. Martins et al. (1998) in an experiment with lemon grass leaves found no statistically significant difference in essential oil content between the drying air velocities used: 0.5 and $1.0 \mathrm{~m} \mathrm{~s}^{-1}$. To evaluate air velocity effects in the drying of lemon grass, Martins et al. (1998) dried lemon grass at 40, 50 and $60{ }^{\circ} \mathrm{C}$ with four conditions of air velocity $(0.8$, $0.6,0.4$ and $0.2 \mathrm{~m} \mathrm{~s}^{-1}$ ). The author observed that at the same temperature, the increase in air velocity promoted an increase in essential oil extraction. The highest essential oil content was obtained at $60^{\circ} \mathrm{C}$ and at $0.8 \mathrm{~m} \mathrm{~s}^{-1}$. The air velocity of $0.2 \mathrm{~m} \mathrm{~s}^{-1}$ provided the lowest mass of essential oil extracted. Figure 3 depicts the curves of thin layer drying leaves Cymbopogon citratus for different temperatures.

\subsection{Mathematical modeling of drying lemon grass}

The effects of drying temperature on the moisture reduction from leaves of lemon grass observed in Figure 3 indicate that the higher the drying temperature the faster water removal from the leaves. Table 2 shows the adjustment of experimental data to thirteen drying mathematical models using non-linear regression, taking into account the different drying temperatures. In all drying conditions the coefficient of determination $\left(\mathrm{R}^{2}\right)$ was greater than 0.99 , signaling according Madamba et al. (1996) a satisfactory drying process (Table 2). The Two Terms model gave the smallest estimated standard error of the mean (SE) and relative mean error magnitude $(\mathrm{P})$ of less than $10 \%$, suitable for describing the process (Tables 3 and 4) according to Mohapatra \& Rao (2005). Regarding the distribution of the residues (Table 5), the two terms model was the most random when fitted to the data by drying at $40,50,60$ and $70{ }^{\circ} \mathrm{C}$, providing the best fits to experimental data. The Diffusion Eight Terms and Exponential models also represented satisfactory drying temperatures of 50 , 60 and $70^{\circ} \mathrm{C}$. The values of the adjusted parameters obtained in each model are shown in Table 6 for the different experimental conditions, especially the model of two terms that best represented the fit of the experimental data of drying. Figure 5 shows a chart that lists the observed and predicted values of moisture due to the different conditions tested. In this figure the adjustment of the humidity with the two terms model to describe the kinetics of

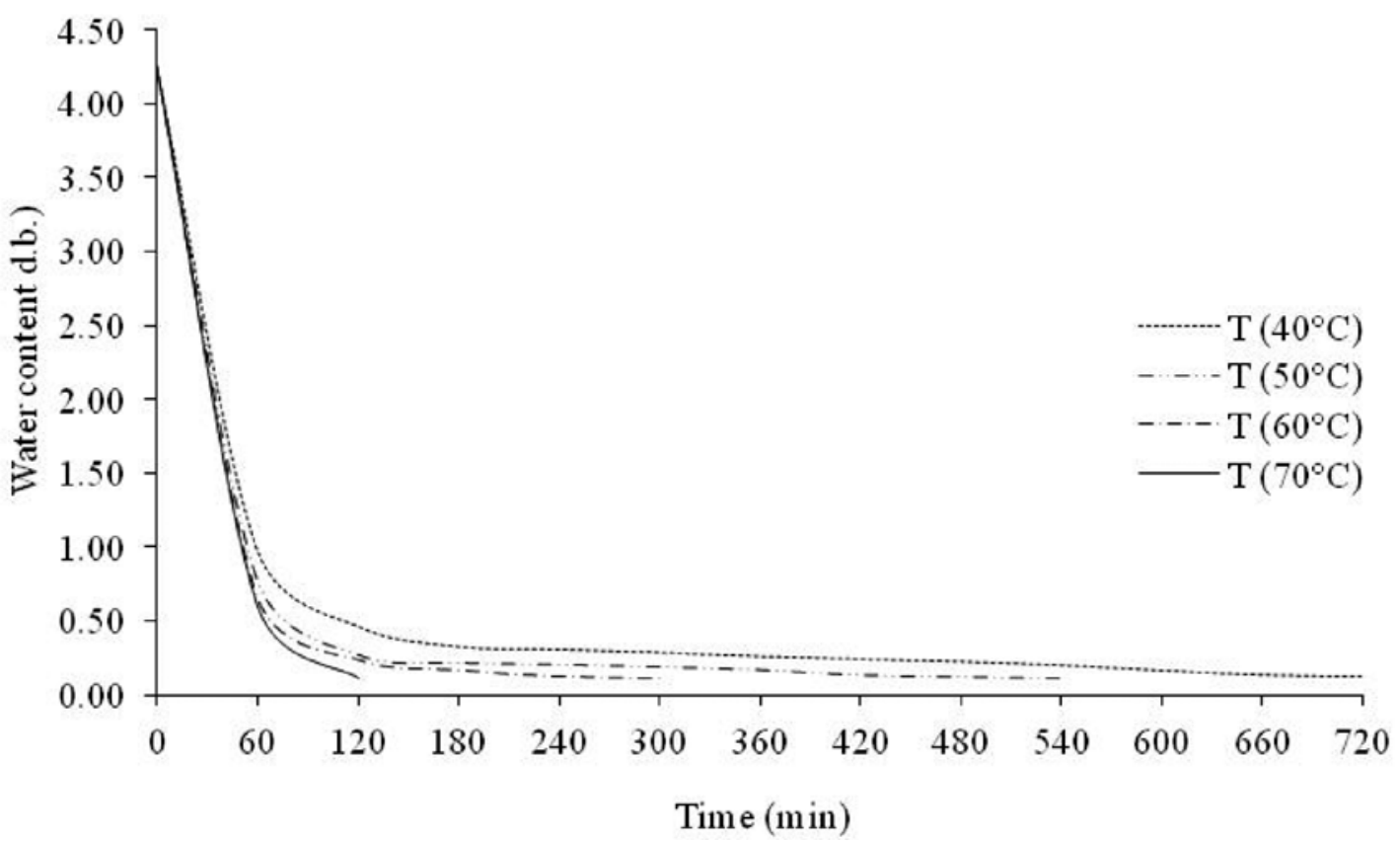

Figure 3. Drying curves versus time for different temperatures of the drying air. 
Table 2. Coefficient of determination $\left(\mathrm{R}^{2}\right)$ of drying of lemon grass (Cymbopogon citratus Stapf) due to different temperatures.

\begin{tabular}{lllll}
\hline \multicolumn{1}{c}{$\begin{array}{c}\text { Mathematical } \\
\text { models }\end{array}$} & \multicolumn{3}{c}{$\mathrm{R}^{2}(\%)$} \\
\cline { 2 - 5 } & $40{ }^{\circ} \mathrm{C}$ & $50{ }^{\circ} \mathrm{C}$ & $60{ }^{\circ} \mathrm{C}$ & $70{ }^{\circ} \mathrm{C}$ \\
\hline Exponential & 98.15 & 99.29 & 99.76 & 99.99 \\
Page & 99.85 & 99.87 & 99.97 & 99.99 \\
Page Modified & 99.85 & 99.87 & 99.97 & 99.99 \\
Thompson & 93.99 & 99.29 & 97.91 & 93.21 \\
Eight Diffusion Terms & 96.70 & 95.68 & 94.25 & 99.99 \\
Henderson and Pabis & 98.16 & 99.29 & 99.76 & 99.99 \\
Logarithmic & 99.84 & 99.96 & 99.99 & 99.99 \\
Two terms & 99.99 & 99.99 & 99.99 & 99.99 \\
Two exponential terms & 98.44 & 99.39 & 99.82 & 99.99 \\
Wang and Sing & 53.62 & 70.82 & 91.37 & 99.99 \\
Henderson and Modified Pabis & 99.99 & 99.99 & 99.47 & 98.85 \\
Midilli et al. & 99.90 & 99.92 & 98.41 & 99.99 \\
Diffusion approximation & 99.56 & 99.72 & 99.99 & \\
\hline
\end{tabular}

Table 3. Values of mean relative error (P) drying of lemon grass (Cymbopogon citratus Stapf) due to different temperatures.

\begin{tabular}{lcccc}
\hline \multicolumn{1}{c}{$\begin{array}{c}\text { Mathematical } \\
\text { models }\end{array}$} & \multicolumn{3}{c}{$\mathrm{P}(\%)$} \\
\cline { 2 - 5 } & $40{ }^{\circ} \mathrm{C}$ & $50{ }^{\circ} \mathrm{C}$ & $60{ }^{\circ} \mathrm{C}$ & $70{ }^{\circ} \mathrm{C}$ \\
\hline Exponential & 2.0631 & 1.7956 & 1.3303 & 0.1048 \\
Page & 0.0652 & 0.1161 & 0.1155 & 0.4567 \\
Page Modified & 0.0652 & 1.8079 & 0.1155 & 1.6745 \\
Thompson & 3.5866 & 1.8079 & 3.9337 & 4.7050 \\
Eight Diffusion Terms & 2.1356 & 1.4567 & 2.1245 & 0.8123 \\
Henderson and Pabis & 5.6069 & 1.8079 & 1.3450 & 0.1076 \\
Logarithmic & 2.3456 & 1.8976 & 0.0221 & 0.0007 \\
Two terms & 0.0038 & 0.0019 & 0.0226 & 0.0076 \\
Two exponential terms & 1.8240 & 1.5943 & 1.0610 & 0.2146 \\
Wang and Sing & 3.0291 & 3.2652 & 2.0560 & 0.0090 \\
Henderson and Modified Pabis & 2.0853 & 0.0007 & 13.9571 & 0.1076 \\
Midilli et al. & 0.0188 & 0.0398 & 1.7369 & 1.4537 \\
Diffusion approximation & 0.9270 & 0.3038 & 0.0225 & 33.3333 \\
\hline
\end{tabular}

Table 4. Estimated values of average error (SE) of drying of lemon grass (Cymbopogon citratus Stapf) due to different temperatures.

\begin{tabular}{lcccc}
\hline \multicolumn{1}{c}{$\begin{array}{c}\text { Mathematical } \\
\text { models }\end{array}$} & \multicolumn{3}{c}{$\mathrm{SE}$ (decimal) } \\
\cline { 2 - 4 } \multicolumn{1}{c}{$4{ }^{\circ} \mathrm{C}$} & $50{ }^{\circ} \mathrm{C}$ & $60{ }^{\circ} \mathrm{C}$ & $70{ }^{\circ} \mathrm{C}$ \\
\hline Exponential & 0.0501 & 0.0357 & 0.0270 & 0.0237 \\
Page & 0.0149 & 0.0160 & 0.0096 & 0.0053 \\
Page Modified & 0.0149 & 0.0160 & 0.0096 & 0.0055 \\
Thompson & 0.0935 & 0.0379 & 0.0880 & 0.1416 \\
Eight Diffusion Terms & 0.0321 & 0.0125 & 0.1235 & 0.4528 \\
Henderson and Pabis & 0.0523 & 0.0379 & 0.0302 & 0.0053 \\
Logarithmic & 0.0161 & 0.0087 & 0.0067 & 0.0063 \\
Two terms & 0.0036 & 0.0038 & 0.0014 & 0.0028 \\
Two exponential terms & 0.0482 & 0.0351 & 0.0256 & 0.0187 \\
Wang and Sing & 0.2313 & 0.2256 & 0.1756 & 0.0348 \\
Henderson and Modified Pabis & 0.0656 & 0.0014 & 0.0887 & 0.0053 \\
Midilli et al. & 0.0131 & 0.0140 & 0.1085 & 0.0299 \\
Diffusion approximation & 0.0267 & 0.0251 & 0.0011 & 0.0007 \\
\hline
\end{tabular}




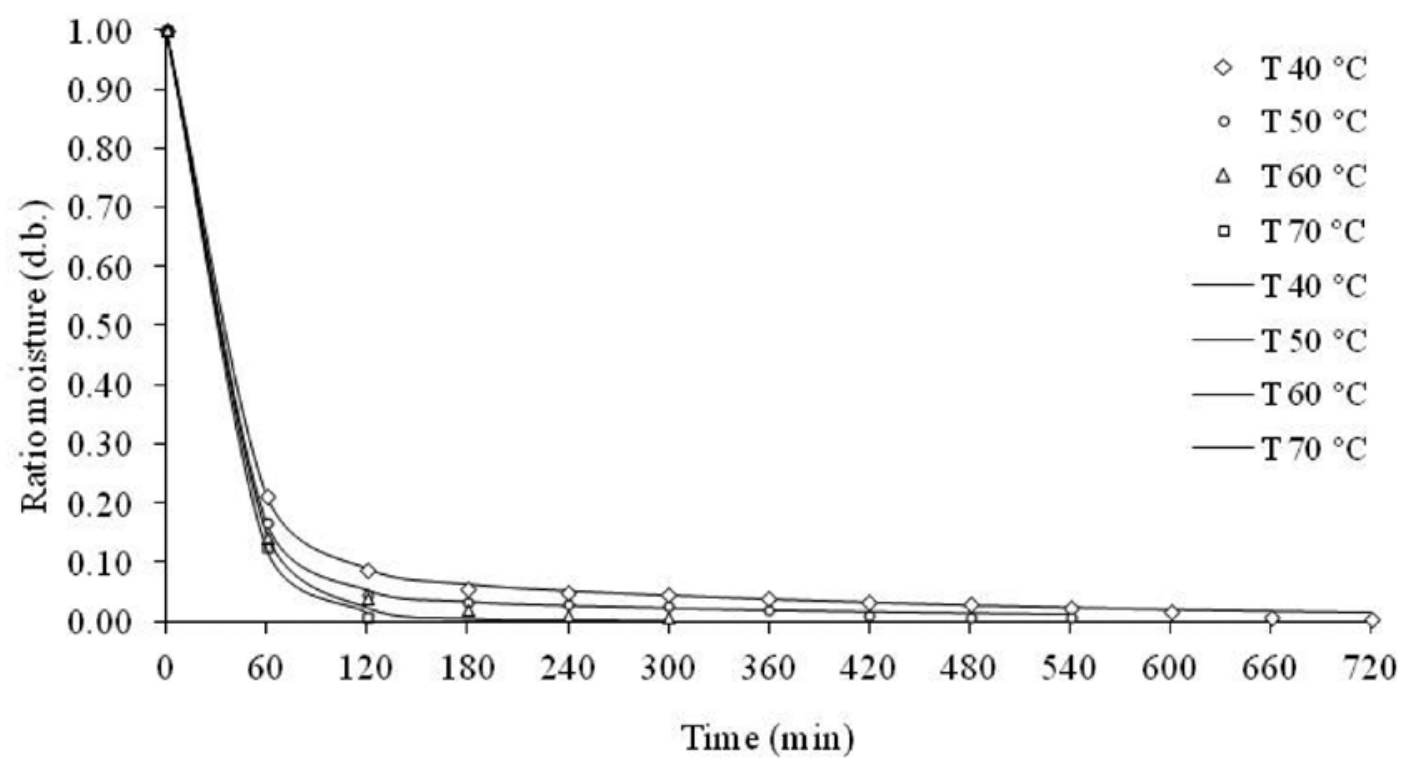

Figure 4. Experimental and estimated values of the moisture ratio by estimating the parameters of the equation of Two Terms.

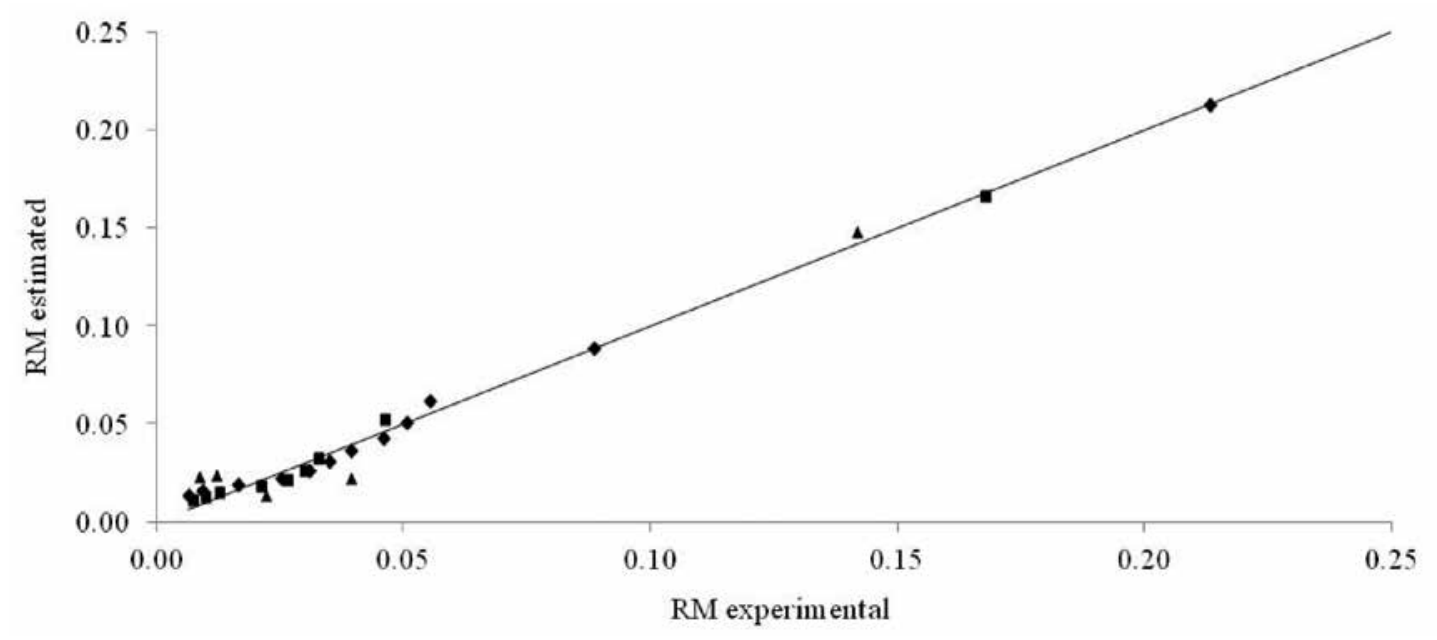

Figure 5. Experimental data and estimated the moisture ratio, calculated by the model of Two Terms.

drying the lemon grass plant may be seen. There was an overestimation of the moisture ratio for most of the experimental values; however, with reduced amounts of the moisture there was a major discrepancy between the experimental data and those estimated by the model. The increased diffusivity values (D) with increasing drying temperature are shown in Figure 6. Doymaz (2006), drying sheets of dill (Anethum graveolens L.), found values of $6.693 \times 10^{-10}, 9.205 \times 10^{-10}$ and $1.434 \times 10^{-9} \mathrm{~m}^{2} \mathrm{~s}^{-1}$ at temperatures of 50,60 and $70{ }^{\circ} \mathrm{C}$, respectively. Akpinar (2006) gave values between $4.53 \times 10^{-12}$ and $7.04 \times 10^{-12} \mathrm{~m}^{2} \mathrm{~s}^{-1}$ for mint (Mentha spp.), parsley (Petroselinum crispum) and basil (Ocimum basilicum). According to Zhang \& Xu (2003), the values of $\mathrm{D}$ for food products lie in the range of $10^{-11}$ to $10^{-9} \mathrm{~m}^{2} \mathrm{~s}^{-1}$. According to equation 20 , the activation energy for liquid diffusion of lemon grass plant was $62.84 \mathrm{~kJ} \mathrm{~mol}^{-1}$. In drying processes the lower the activation energy, the higher the diffusivity of water in the product. The activation energy found in this study was similar to those obtained by Doymaz (2006) for leaves of Mentha spicata L. $\left(62.96 \mathrm{~kJ} \mathrm{~mol}^{-1}\right)$. 
Table 5. Evaluation of the distribution of residuals for models fitted to experimental data of drying of lemon grass (Cymbopogon citratus Stapf).

\begin{tabular}{lcccc}
\hline \multirow{2}{*}{$\begin{array}{c}\text { Mathematical } \\
\text { models }\end{array}$} & \multicolumn{4}{c}{ Distribution of waste } \\
\cline { 2 - 5 } \multicolumn{1}{c}{$40^{\circ} \mathrm{C}$} & $50{ }^{\circ} \mathrm{C}$ & $60{ }^{\circ} \mathrm{C}$ & $70{ }^{\circ} \mathrm{C}$ \\
\hline Exponential & $\mathrm{T}$ & $\mathrm{A}$ & $\mathrm{A}$ & $\mathrm{A}$ \\
Page & $\mathrm{A}$ & $\mathrm{T}$ & $\mathrm{A}$ & $\mathrm{A}$ \\
Page Modified & $\mathrm{A}$ & $\mathrm{T}$ & $\mathrm{T}$ & $\mathrm{A}$ \\
Thompson & $\mathrm{T}$ & $\mathrm{T}$ & $\mathrm{T}$ & $\mathrm{A}$ \\
Eight Diffusion Terms & $\mathrm{T}$ & $\mathrm{A}$ & $\mathrm{A}$ & $\mathrm{A}$ \\
Henderson and Pabis & $\mathrm{T}$ & $\mathrm{T}$ & $\mathrm{A}$ & $\mathrm{A}$ \\
Logarithmic & $\mathrm{T}$ & $\mathrm{T}$ & $\mathrm{A}$ & $\mathrm{A}$ \\
Two terms & $\mathrm{T}$ & $\mathrm{T}$ & $\mathrm{T}$ & $\mathrm{T}$ \\
Two exponential terms & $\mathrm{T}$ & $\mathrm{T}$ & $\mathrm{T}$ & $\mathrm{A}$ \\
Wang and Sing & $\mathrm{T}$ & $\mathrm{T}$ & $\mathrm{T}$ & $\mathrm{A}$ \\
Henderson and Modified Pabis & $\mathrm{T}$ & $\mathrm{T}$ & $\mathrm{A}$ & $\mathrm{A}$ \\
Midilli et al. & $\mathrm{T}$ & $\mathrm{T}$ & $\mathrm{T}$ & $\mathrm{A}$ \\
Diffusion approximation & $\mathrm{T}$ & $\mathrm{T}$ & $\mathrm{A}$ & $\mathrm{T}$ \\
\hline
\end{tabular}

$$
D=3.17 \times 10^{-5} \exp \left(-\frac{6284.077}{R . T a}\right)
$$

The Arrhenius representation showed uniform variation of diffusivity with temperature; the description of $\ln \mathrm{D}$ as a function of reciprocal temperature $(1 / \mathrm{T})$ is shown in Figure 7. According to Figure 8, the heat isosteric integral of Cymbopogon citratus Stapf varied from $2232.795 \mathrm{~kJ} \mathrm{~kg}^{-1}$ to $2144.423 \mathrm{~kJ} \mathrm{~kg}^{-1}$. Figure 8 shows that an increase of energy was required for the removal of product water, represented by integral values of isosteric heat of desorption $\left(\mathrm{Q}_{\mathrm{st}}\right)$, as observed for several agricultural products (Jayendra et al. 2005). Brooker et al. (1992) and Khatchatourian (2012) stated that in order to remove water from grains with low water content a greater amount of energy is required on average than that required for wet products. These results confirm the fact that in products with higher water content the bonding force between the molecules of water and dry matter decreases significantly. Possible differences between the observed values of integral isosteric heat of sorption for different products can be justified, and the factors inherent in the products themselves; according to Hemis et al. (2012) there are possible errors in the determination of the values of water activity of each of equilibrium water content, since the values were obtained from the mathematical model. Despite these discrepancies, Zhang \& Xu (2003), studying water sorption isotherms of some vegetables at temperatures of 30 to $60{ }^{\circ} \mathrm{C}$, concluded that the isosteric heat of desorption can be used to estimate the energy required in the process of dehydration of agricultural products.

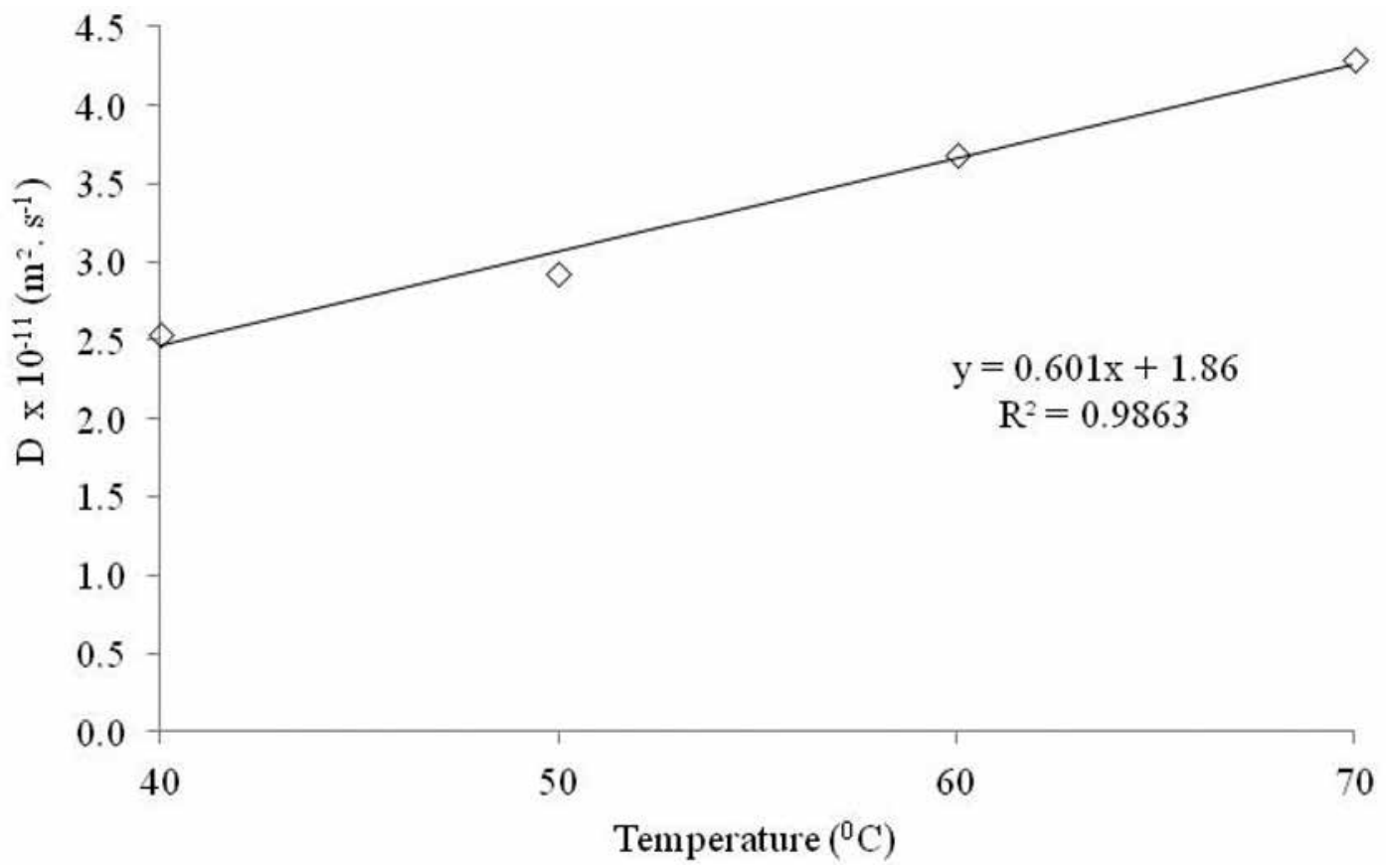

Figure 6. Mean values for the effective diffusion coefficient $\left(\mathrm{m}^{2} \mathrm{~s}^{-1}\right)$, due to different air temperatures in the drying of lemon grass (Cymbopogon citratus Stapf). 
Table 6. Parameters obtained from models fitted to the data for drying of lemon grass (Cymbopogon citratus Stapf)*.

\begin{tabular}{|c|c|c|c|c|c|c|c|}
\hline Mathematical models & $\mathrm{T}\left({ }^{\circ} \mathrm{C}\right)$ & $\mathrm{K}$ & & & & & \\
\hline \multirow[t]{5}{*}{ Exponencial } & 40 & 0.021782 & & & & & \\
\hline & 50 & 0.026669 & & & & & \\
\hline & 60 & 0.029555 & & & & & \\
\hline & 70 & 0.032668 & & & & & \\
\hline & $\mathrm{T}\left({ }^{\circ} \mathrm{C}\right)$ & $\mathrm{K}$ & $\mathrm{n}$ & & & & \\
\hline \multirow[t]{5}{*}{ Page } & 40 & 0.397076 & 0.337252 & & & & \\
\hline & 50 & 0.394883 & 0.370576 & & & & \\
\hline & 60 & 0.247741 & 0.495543 & & & & \\
\hline & 70 & 0.048303 & 0.905750 & & & & \\
\hline & $\mathrm{T}\left({ }^{\circ} \mathrm{C}\right)$ & $\mathrm{k}$ & $\mathrm{n}$ & & & & \\
\hline \multirow[t]{5}{*}{ Page Modified } & 40 & 0.064655 & 0.337252 & & & & \\
\hline & 50 & 0.081484 & 0.370575 & & & & \\
\hline & 60 & 0.059855 & 0.495541 & & & & \\
\hline & 70 & 0.035238 & 0.905797 & & & & \\
\hline & $\mathrm{T}\left({ }^{\circ} \mathrm{C}\right)$ & $\mathrm{a}$ & $\mathrm{b}$ & & & & \\
\hline \multirow[t]{5}{*}{ Thompson } & 40 & -0.951500 & 1.826723 & & & & \\
\hline & 50 & 0.002040 & 0.163197 & & & & \\
\hline & 60 & -0.951470 & 1.826728 & & & & \\
\hline & 70 & -0.095140 & 1.826729 & & & & \\
\hline & $\mathrm{T}\left({ }^{\circ} \mathrm{C}\right)$ & D & & & & & \\
\hline \multirow[t]{5}{*}{ Eight Diffusion Terms } & 40 & $2.33 \times 10^{-5}$ & & & & & \\
\hline & 50 & $2.76 \times 10^{-5}$ & & & & & \\
\hline & 60 & $3.44 \times 10^{-5}$ & & & & & \\
\hline & 70 & $4.15 \times 10^{-5}$ & & & & & \\
\hline & $\mathrm{T}\left({ }^{\circ} \mathrm{C}\right)$ & $\mathrm{a}$ & $\mathrm{k}$ & & & & \\
\hline \multirow[t]{5}{*}{ Henderson and Pabis } & 40 & 0.993407 & 0.021664 & & & & \\
\hline & 50 & 0.997958 & 0.026633 & & & & \\
\hline & 60 & 0.998785 & 0.029534 & & & & \\
\hline & 70 & 0.999899 & 0.326660 & & & & \\
\hline & $\mathrm{T}\left({ }^{\circ} \mathrm{C}\right)$ & $\mathrm{a}$ & $\mathrm{k}$ & $\mathrm{c}$ & & & \\
\hline \multirow[t]{5}{*}{ Logarithmic } & 40 & 0.945515 & 0.026973 & 0.053409 & & & \\
\hline & 50 & 0.960554 & 0.031267 & 0.039281 & & & \\
\hline & 60 & 0.967522 & 0.033893 & 0.032334 & & & \\
\hline & 70 & 0.992633 & 0.033620 & 0.073670 & & & \\
\hline & $\mathrm{T}\left({ }^{\circ} \mathrm{C}\right)$ & $\mathrm{a}$ & $\mathrm{K}_{0}$ & $\mathrm{~b}$ & $\mathrm{k}_{1}$ & & \\
\hline \multirow[t]{5}{*}{ Two Terms } & 40 & 0.106667 & 0.001632 & 0.893344 & 0.031594 & & \\
\hline & 50 & 0.065669 & 0.001516 & 0.934423 & 0.033776 & & \\
\hline & 60 & 0.067312 & 0.003302 & 0.932686 & 0.499392 & & \\
\hline & 70 & 0.499950 & 0.032666 & 0.499950 & 0.032666 & & \\
\hline & $\mathrm{T}\left({ }^{\circ} \mathrm{C}\right)$ & $\mathrm{a}$ & $\mathrm{k}$ & & & & \\
\hline \multirow[t]{5}{*}{ Two exponential terms } & 40 & 0.353422 & 0.045071 & & & & \\
\hline & 50 & 0.387352 & 0.051502 & & & & \\
\hline & 60 & 0.395577 & 0.056767 & & & & \\
\hline & 70 & 0.221456 & 0.129494 & & & & \\
\hline & $\mathrm{T}\left({ }^{\circ} \mathrm{C}\right)$ & $\mathrm{a}$ & $\mathrm{b}$ & & & & \\
\hline \multirow[t]{5}{*}{ Wang and Sing } & 40 & -0.048360 & 0.000050 & & & & \\
\hline & 50 & -0.006482 & 0.000090 & & & & \\
\hline & 60 & -0.010902 & 0.000027 & & & & \\
\hline & 70 & 0.020561 & 0.000104 & & & & \\
\hline & $\mathrm{T}\left({ }^{\circ} \mathrm{C}\right)$ & $\mathrm{a}$ & $\mathrm{k}$ & $\mathrm{b}$ & $\mathrm{k}_{0}$ & $\mathrm{c}$ & $\mathrm{k}_{1}$ \\
\hline Henderson and Pabis & 40 & 0.457726 & 0.031585 & 0.435517 & 0.031626 & 0.106769 & 0.001635 \\
\hline \multirow[t]{3}{*}{ Modified } & 50 & 3.162981 & 0.024216 & 0.098649 & -0.00247 & -2.26162 & -0.02103 \\
\hline & 60 & 0.320483 & 0.035132 & 0.320483 & 0.35132 & 0.320483 & 0.035132 \\
\hline & 70 & 0.333300 & 0.032666 & 0.333300 & 0.032666 & 0.333300 & 0.032666 \\
\hline
\end{tabular}




\begin{tabular}{lccccc}
\hline Mathematical models & $\mathrm{T}\left({ }^{\circ} \mathrm{C}\right)$ & $\mathrm{K}$ & & & \\
\hline & $\mathrm{T}\left({ }^{\circ} \mathrm{C}\right)$ & $\mathrm{a}$ & $\mathrm{k}$ & $\mathrm{n}$ & $\mathrm{B}$ \\
Midilli et al. & 40 & 1.000234 & 0.253595 & 0.439597 & 0.000043 \\
& 50 & 1.006629 & 0.279694 & 0.454165 & 0.000042 \\
& 60 & 1.000000 & 7.169768 & 1.496796 & 0.000192 \\
& 70 & 1.000000 & 2.314524 & 0.817317 & 0.000631 \\
Diffusion & $\mathrm{T}\left({ }^{\circ} \mathrm{C}\right)$ & $\mathrm{a}$ & $\mathrm{k}$ & $\mathrm{b}$ & \\
approximation & 40 & 0.827413 & 0.033031 & 0.141289 & \\
& 50 & 0.776262 & 0.515767 & 0.011981 & \\
& 60 & 0.932745 & 0.036945 & 0.089254 & \\
\hline
\end{tabular}

* All estimated coefficients were significant at $5 \%$ probability by $\mathrm{t}$ test.

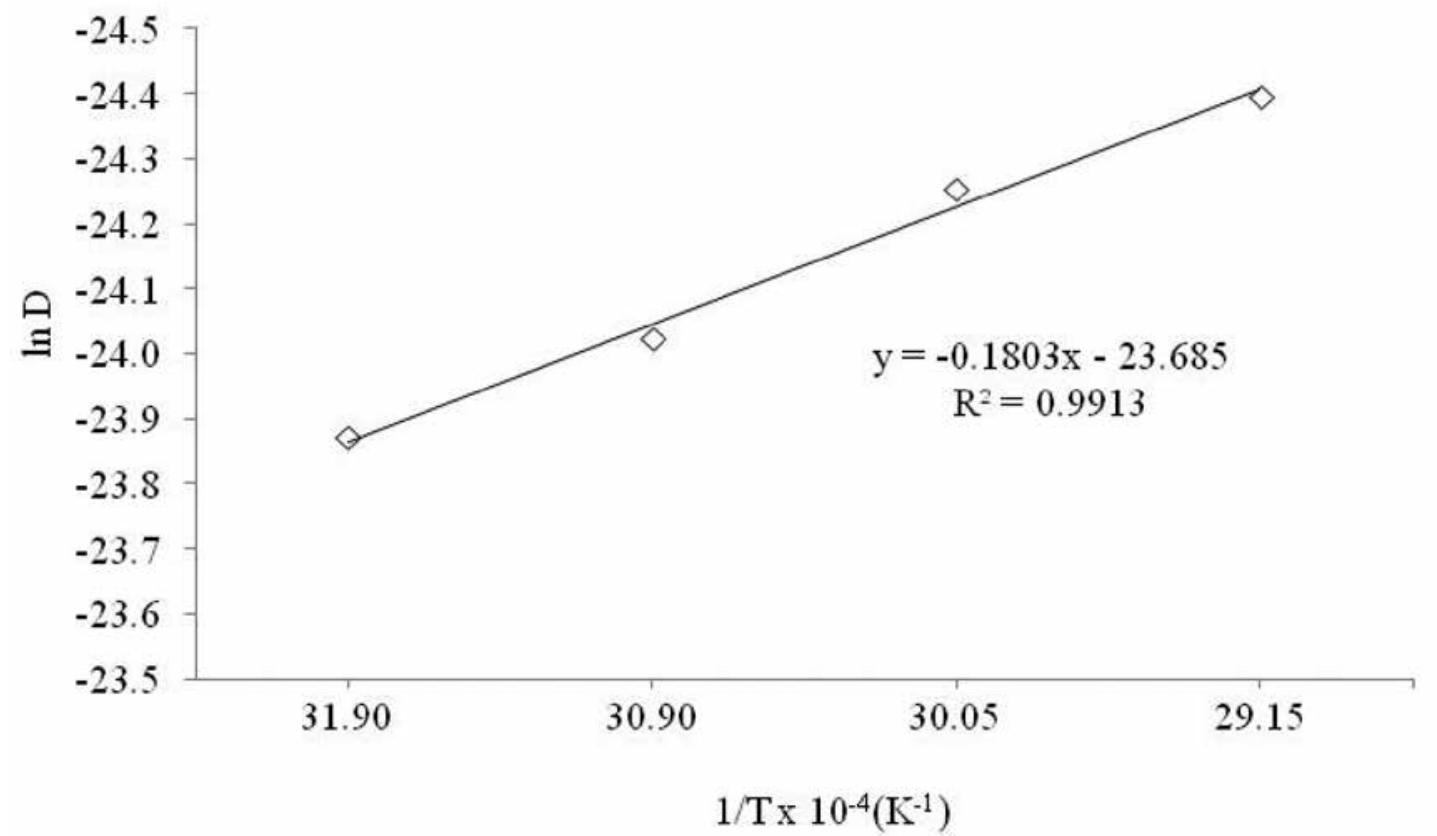

Figure 7. Representation of the Arrhenius relationship for the effective diffusivity and air temperature drying of lemon grass (Cymbopogon citratus Stapf).

\subsection{Essential oil content}

Figure 9 shows that there were reductions in levels of essential oils $(p>0.05)$ in dry plants for different temperatures of the drying air. It was also observed that increasing the drying temperature influenced negatively the amount of essential oil. In the fresh plant oil content was $1.12 \%$ (d.b.); however, when the drying plant has a temperature of $40{ }^{\circ} \mathrm{C}$, the oil content was reduced to $0.89 \%(\mathrm{db})$. Buggle et al. (1999) carried out the drying of lemon grass in an oven heated to $30,50,70$ and $90{ }^{\circ} \mathrm{C}$ to constant weight to evaluate the quantity and quality of essential oil. The best results were obtained for the essential oil content by drying at $50{ }^{\circ} \mathrm{C}(1.43 \%)$; although the treatment at $30{ }^{\circ} \mathrm{C}(1.34 \%)$ showed significant difference with $50{ }^{\circ} \mathrm{C}$ it is not indicated, because it favored fungus growth. Treatment at 70 and $90{ }^{\circ} \mathrm{C}$ (1.19 and $1.06 \%$ respectively) showed significant reduction in the essential oil content compared to the other treatments. The worst results were obtained at the drying temperature of $70{ }^{\circ} \mathrm{C}$ (Figure 9) which reduced the amount of oil to $0.34 \%$ (d.b.). Radünz et al. (2010) used 5 temperatures (ambient air and heated air at $40,50,60$ and $70^{\circ} \mathrm{C}$ ) for the drying of Lippia sidoides Cham, compared to the fresh plant, to evaluate essential oil content. For the sample dried with environmental air a significant reduction of $8 \%$ in the essential oil content was observed, while drying at $40,50,60$ and $70{ }^{\circ} \mathrm{C}$ showed no significant 


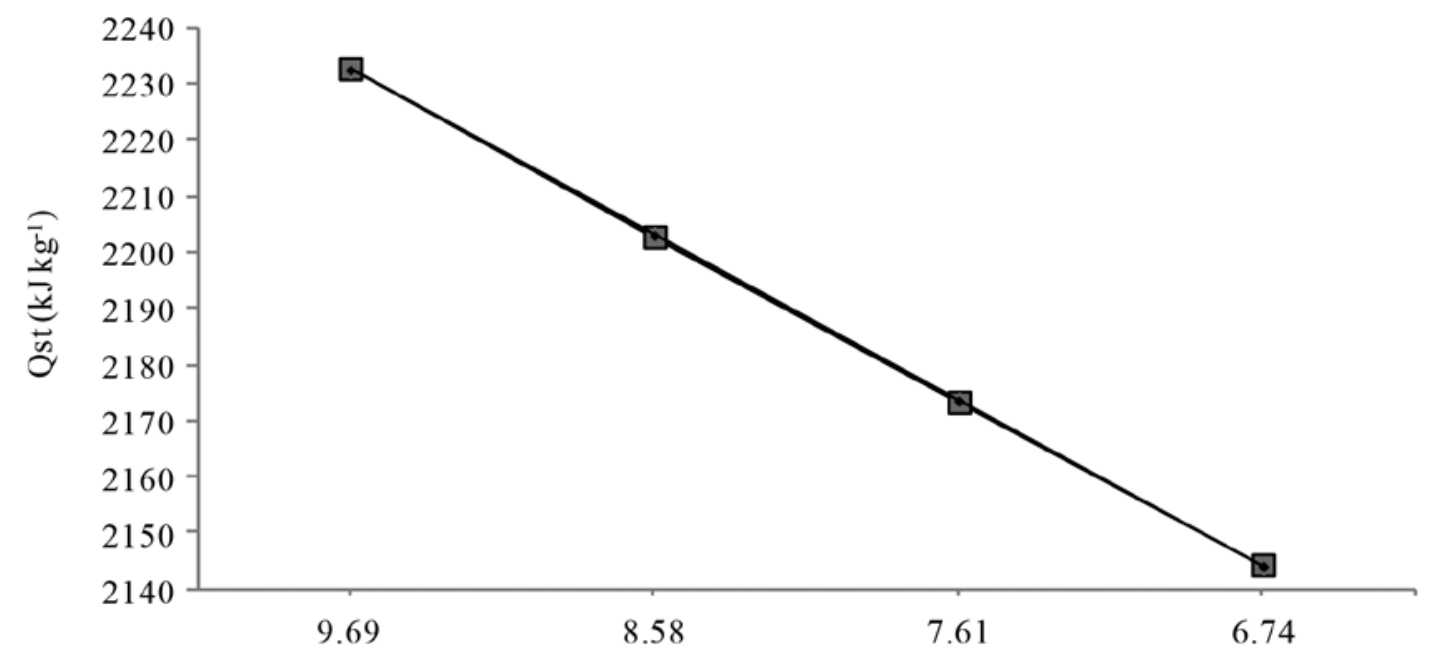

Equilibrium moisture, \% (d.b.)

Figure 8. Experimental values and estimated integral isosteric heat of sorption as a function of moisture content equilibrium.

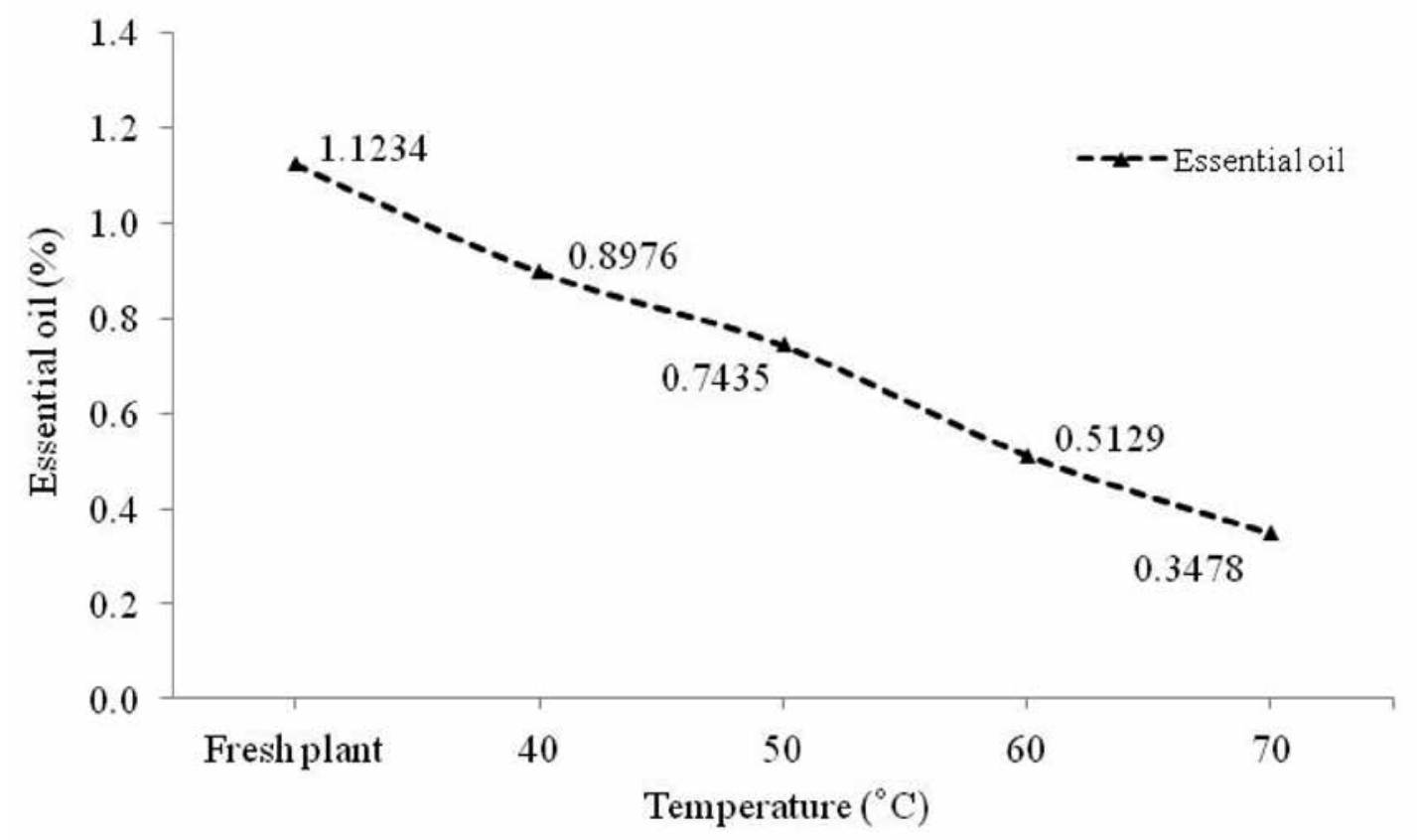

Figure 9. Performance of essential oils according to the temperature of the drying air.

differences with fresh plants. In a study carried out to determine the drying type and fragmentation of lemon grass leaves to optimize the essential oil content, 6 drying treatments were established, including 2 drying types (oven with forced ventilation at $40^{\circ} \mathrm{C}$ and room temperature with dehumidifiers) and 3 sizes of dried leaves fragments (pulverized, 1 $\mathrm{cm}$ fragments and $20 \mathrm{~cm}$ fragments). The authors concluded that the highest essential oil content was obtained with the samples dried at room temperature with dehumidifiers, with no significant differences for the leaf sizes (Martinazzo et al. (2010). Evaluating the 
influence of the drying air temperature on Ocimum selloi Benth essential oil content, Martinazzo et al. (2010) observed that the essential oil content did not show significant variation. Radünz et al. (2010) used common mint (Mentha $x$ villosa Huds), drying it on a fixed-bed dryer with ambient air and air heated to $40,50,60,70$ and $80^{\circ} \mathrm{C}$ and evaluated the essential oil content extracted after drying with that extracted from fresh plants. They concluded that the highest content was obtained when the drying process was done with drying air at $50{ }^{\circ} \mathrm{C}$. The highest value of drying air velocity found in the literature for drying medicinal plants was $3.3 \mathrm{~m} \mathrm{~s}^{-1}$, used by Venskutonis et al. (1996) in drying Thymus vulgaris and Salvia officinalis. Radünz et al. (2010) observed that the essential oil of Ocimum basilicum $\mathrm{L}$ was affected by both temperature and air velocity during drying. Muller et al. (1992) used $0.2 \mathrm{~m} \mathrm{~s}^{-1}$ in drying leaves of Salvia officinalis. Martins et al. (1998) observed, in an experiment with lemon grass leaves, no statistically significant difference in final product quality for both drying air velocities used: 0.5 and $1.0 \mathrm{~m} \mathrm{~s}^{-1}$.

\section{Conclusion}

The essential oil content extracted from dried plants at $0.8 \mathrm{~m} \mathrm{~s}^{-1}$ and $1.3 \mathrm{~m} \mathrm{~s}^{-1}$ with manual control system was not affected by the drying process. The temperature of the drying air had a negative influence on the levels of the essential oil of the plant. Drying with automatic control caused reduction in the essential oil content for all velocities studied compared to the fresh plant. Increments in the temperature of drying air significantly reduced the drying time. The mathematical model of two terms is adequate to describe the drying process of lemon grass plants (Cymbopogon citratus Stapf). Diffusion values increased with increasing temperature of the drying air, while the value of activation energy was $62.84 \mathrm{~kJ} \mathrm{~mol}^{-1}$.

\section{Acknowledgment}

The authors express their thanks to CNPq, CAPES and FAPEMIG for the financial support essential for conducting the project.

\section{Literature Cited}

\section{Akpinar, E.K.}

2006. Mathematical modelling of thin layer drying process under open sun of some aromatic plants. Journal of Food Engineering, London, 77 (4): 864-870.

ASAE Standards

2000. Standards Engineering Practices Data: Moisture measurement-forages, Adopted and published by: American Society of Agricultural Engineers, 565-72.

Baritaux, O.; Richard, H.; Touche, J.; Derbesy, M.

1992. Effects of drying and storage of herbs and spices on the essential oil. Part I. Basil, ocimum basilicum L. Flavour Fragr. J., (7): 267-271.

Buggle, V.; Ming, L.C.; Furtado, E.L.; Rocha, S.F.R.; Marques, M.O.M.

1999. Influence of different drying temperatures on the amount of essential oils and citral content in cymbopogon citratus (dc) stapf-poaceae. Acta Hort. (ISHS), (500): 71-74.

Brooker, D.B.; Baker-Arkema, F.W.; Hall, C.W. 1992. Drying and storage of grains and oilseeds. New York: AVI Book, $450 \mathrm{p}$.

Castro, H.G.; Ferreira, F.A.

2001. Contribuição ao estudo das Plantas Medicinais: carqueja (Baccharis genistelloides). Viçosa, 102 p.

Corrêa, P.C.; Afonso Junior, P.C.; Martins, P.M.; Melo, E.C.; Radunz, L.L.

2002. Modelo matemático para representação da higroscopicidade de plantas medicinais. Revista Brasileira de Armazenamento, 27 (1): 10-16.
Demir, V.; Gunhan, T.; Yagcioglu, A.K.; Degirmencioglu, A. 2004. Mathematical modelling and the determination of some quality parameters of air-dried bay leaves. Biosystems Engineering, Edinburgh, 88 (3): 325-335.

Doymaz, I.

2006.Thin-layer drying behaviour of mint leaves. Journal of Food Engineering, Davis, 74 (3): 370-375.

Hansen, J.A.; Nelssen, J.L.; Goodband, R.D.

1993. Evaluation of animal protein supplements of earlyweaned pigs. J. Anim. Sci., (71): 1853-1862.

Hemis, M.; Choudhary, R.; Watson, D.G.

2012. A coupled mathematical model for simultaneous microwave and convective drying of wheat seeds, Biosystems Engineering, 112 (3): 202-209.

Jayendra, K.A.; Singh, R.R.B.; Patil, G.R.; Patel, A.A. 2005. Effect of temperature on moisture desorption isotherms of kheer. LWT-Food Science and Technology, 38: 303-310.

Khatchatourian, O.A.

2012. Experimental study and mathematical model for soya bean drying in thin layer, Biosystems Engineering, 113 (1): 54-64.

Madamba, P.S.; Driscoll, R.H.; Buckle, K.A.

1996. Thin layer drying characteristics of garlic slices. Journal of Food Engineering, Davis, 29 (1): 75-97.

Martinazzo, A.P.; Melo, E.C.; Corrêa, P.C.; Santos, R.H.S.

2010. Modelagem matemática e parâmetros qualitativos da secagem de folhas de capim-limão Cymbopogon citratus D. C. Stapf. Rev. bras. plantas med., 12: 488-498.

Martins, E.R.; Castro, D.M.; Castellani, D.M.; Dias, J.E. 1998. Plantas Medicinais. Viçosa: Editora UFV, 220 p. 
Mohapatra, D.; Rao, P.S.

2005. A thin layer drying model of parboiled wheat. Journal of Food Engineering, Davis, 66 (4): 513-518.

Muller, J.; Koll-Weber, M.; Kraus, W.

1992. Effect of drying on the essential oil of Salvia officinalis. In Annual Congress on Medicinal Plant Research, 40, 1992, New York. Proceedings... New York: Thieme, p. 104.

Panchariya, P.C.; Popovic, D.; Sharma, A.L.

2002. Thin-layer modeling of black tea drying process. Journal of Food Engineering, Davis, 52 (4): 349-357.

Park, K.J.; Vohnikova, Z.; Brod, F.P.R.

2002. Evaluation of drying parameters and desorption isotherms of garden mint leaves (Mentha crispa L.). Journal of Food Engineering, 51: 15-25.

Prates, M.O.; Pizziolo, T.A.; Melo, E.C.; Rocha, R.P.; Nicácio, J.V. 2011. Controle da temperatura e velocidade do ar de secagem em um secador de plantas medicinais. Revista Engenharia na Agricultura, 19: 101-111.
Radünz, L.L.; Melo, E.C.; Rocha, P.P.; Berbert, P.A.; Gracia,

L.M.N.

2010. Study of essential oil from guaco leaves submitted to different drying air temperature. Engenharia na Agricultura, 18: 241-247.

Thompson, T.L.; Peart, R.M.; Foster, G.H.

1968. Mathematical simulation of corn drying: A new model. Transactions of ASAE, St. Joseph, 11 (4): 582-586.

Venskutonis, R.; Poll, L.; Larsen, M.

1996. Influence of drying and irradiation on the composition of volatile compounds of thyme (Thymus vulgaris L.). Flavour and Fragance Journal, 11: 123-8.

Zhang, M.; Xu, Y.Y.

2003. Research developments of combination drying technology for fruits and vegetables at home and abroad. Journal of Wuxi University of Light Industry, 22 (6): 103-106.

Nomenclature

\begin{tabular}{|c|c|}
\hline RU & moisture ratio, dimensionless \\
\hline $\mathrm{t}$ & drying time, $\mathrm{h}$; \\
\hline $\mathrm{k}, \mathrm{k}_{\mathrm{o}}, \mathrm{k}_{1}$ & drying constant, $\mathrm{h}^{-1}$ \\
\hline $\mathrm{a}, \mathrm{b}, \mathrm{c}, \mathrm{n}$ & model coefficients; \\
\hline$n$ & number of terms of the equation; \\
\hline $\mathrm{D}$ & diffusion coefficient, $\mathrm{m}^{2} \mathrm{~s}^{-1}$ \\
\hline $\mathrm{L}$ & product thickness, $\mathrm{m}$ \\
\hline $\mathrm{U}^{*}$ & water content of product (d.b.), \% \\
\hline $\mathrm{Ui}^{*}$ & initial water content of the product (d.b.), \% \\
\hline $\mathrm{Ue}^{*}$ & equilibrium water content of the product (d.b.), \% \\
\hline A & constant, $\mathrm{m}^{2} \mathrm{~s}^{-1}$ \\
\hline $\mathrm{E}$ & activation energy, $\mathrm{kJ} \mathrm{kmol}^{-1}$ \\
\hline $\mathrm{R}$ & universal gas constant, $8,314 \mathrm{~kJ} \mathrm{kmol}^{-1} \mathrm{~K}^{-1}$ \\
\hline $\mathrm{T}_{\mathrm{abs}}$ & absolute temperature, $\mathrm{K}$ \\
\hline $\mathrm{Y}$ & experimentally observed value \\
\hline$\hat{Y}$ & value calculated by the model \\
\hline $\mathrm{n}$ & number of experimental observations \\
\hline
\end{tabular}

